\section{Bird flu spreading in Asia}

$\mathrm{B}$ ird flu continues to hover as a spectre over much of Asia as more nations report that the $\mathrm{H}_{5} \mathrm{NI}$ virus has been found within their fowl and fears rise that it could mutate into a form that leads to human-to-human transmission and kills far more than the 200 people around the world who have died from the infectious disease since 2003.

India has become the latest nation to be affected by an outbreak of bird $\mathrm{flu}$, as the virus was recently detected in I3 of I9 districts in the eastern state of West Bengal. More than 3 million birds have been culled since mid-January and experts have attributed the outbreak to such factors as smuggling of poultry from bird flu affected Bangladesh and inadequate culling initiatives. But while individuals have been isolated because of suspicious symptoms, no human case of bird flu has been reported.

The virus has been detected in 47 of 64 districts in Bangladesh, where about I.25 million birds have been slaughtered since March 2007, at a projected US $\$ 650$ million cost to the economy. As in India, no human case has been reported, although on Mar. 6 , 2008 , the owner of an infected poultry farm and his family were quarantined.

"West Bengal state of India and Bangladesh has similarities in terms of environment, which is why it appears that there may be some common environmental factors that worked behind the spread of the $\mathrm{H}_{5} \mathrm{NI}$ virus in both the countries," says Swapan Jana, secretary of the Society for Social Pharmacology, an Indian nongovernmental organization. Factors that may play a role in possible human infection could include the fact that "both the countries are densely populated, a large number of common masses lack health consciousness in both the countries and many people, particularly in rural areas, keep poultry in their houses."

Indonesia continues to be the worst hit by the disease, with II people having already died this year, raising the nation's total number of deaths caused by bird flu to 105. "Poor hygiene, close contact between human beings and poultry, lack of proper medical care include some of the factors, which may contribute behind the human deaths due to bird flu in Indonesia," Jana says.

In Thailand, where 17 deaths from bird flu have been reported since 2004, no human case has been detected in 2008, but $\mathrm{H}_{5} \mathrm{NI}$ was recently detected at a poultry farm.

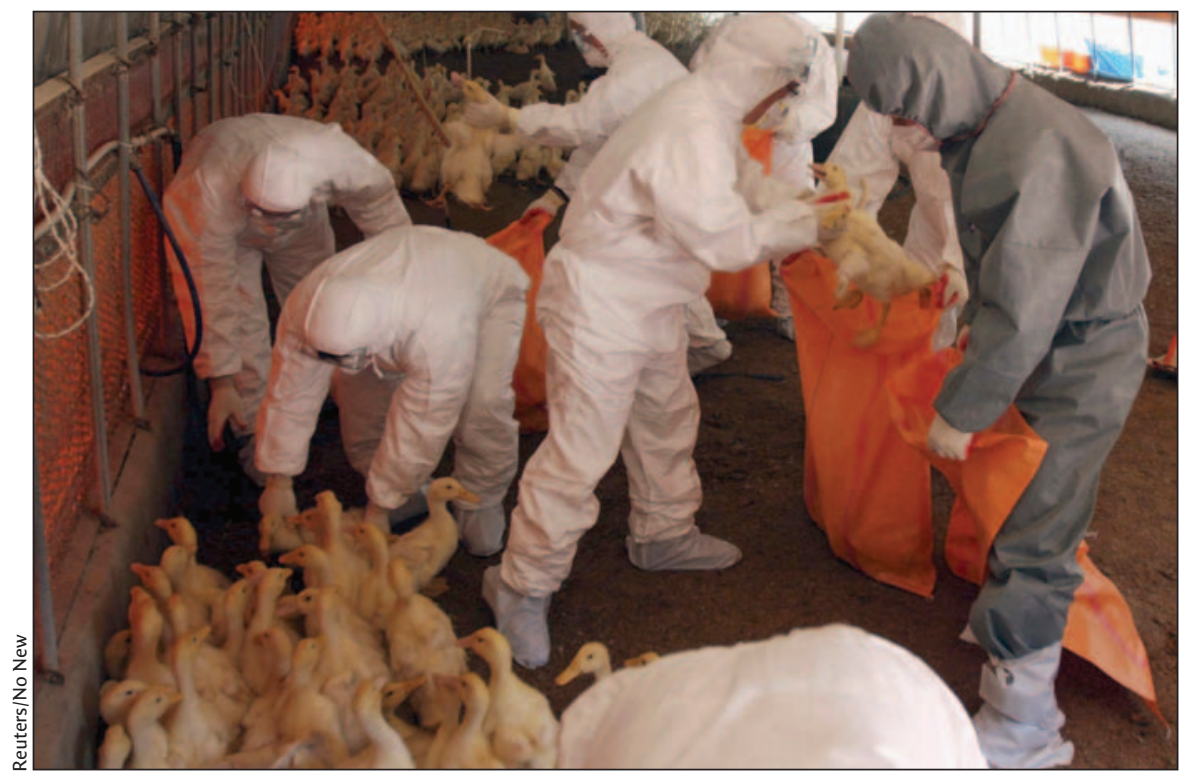

Health officials put ducks into sacks at a farm in Muan, about $390 \mathrm{~km}$ south of Seoul on Apr. 18, 2008. South Korea confirmed a new outbreak of bird flu at a duck farm in Jeongeup and said it was investigating 2 other possible cases days after reporting an outbreak at a nearby chicken farm.
In Myanmar, I case of human infection was reported in December 2007, while China reports that 3 humans have died from bird flu thus far this year and that a father caught bird flu from his son in December 2007. Vietnam's death toll is 4 , but io provinces have detected the virus this year and over 30 ooo fowl have been culled. Poultry have also been infected in Laos, Pakistan and Nepal.

The ongoing risk to humans remains large, WHO spokesperson Gregory Hartl stated in an email interview. "As long as the $\mathrm{H}_{5} \mathrm{NI}$ virus remains so widely entrenched in animals, there is always the possibility that the virus may mutate into a form which is easily transmissible among humans." - Sanjit Bagchi MBBS, Kolkata, India

DOI:Io.I503/cmaj.080526

\section{Annual residency scramble}

\section{near completion}

A lthough a record 353 international medical school graduates found positions in the 2008 residency match as provinces slowly moved to fulfill commitments to expand slots for those educated or trained abroad, some 946 international graduates and an estimated 85 Canadian medical school graduates are scrambling for the remaining I2I spots available in the annual competition.

The remaining spots are projected to be filled by mid-June. Canadian Resident Match Service Executive-Director Sandra Banner says that 2 of the spots are specifically designated for international graduates, while the remaining II are open to either Canadian or international graduates.

Banner said that $4 \%$ of 2 I43 Canadian applicants remain unmatched after the first 2 iterations. That translates into 85 graduates. In theory, they have the upper hand in the competition for the remaining unmatched I2I residency slots as all Canadian medical school graduates are guaranteed residency spots, if they desire them. That leaves only 36 still up for grabs by international graduates. 
Banner says that about half of the international medical graduates who found positions, and $31 \%$ of the Canadian graduates, will pursue residencies in family practice. Last year, $29 \%$ of Canadian medical school graduates made that choice. The percentage has consistently hovered around 30\% in recent years. The numbers for specialities were not available as of CMAJ's press deadline but apparently are also consistent with previous years.

"The match is pretty predictable for Canadians," Banner said, adding that the picture is improving for international graduates. "One of the things we can all be comfortable with is that the commitment to ensuring there are positions for international medical graduates in our system is stabilizing."

Overall, the number of available residencies was the highest ever. On July I, 2008, 2478 medical school graduates will begin post-graduate training, breaking the previous record of 2337 , set last year. The 353 placements from foreign medical schools eclipsed last year's record of 298 .

"Each of the provinces has made a firm commitment to funding positions for international graduates," Banner said.

Canadian medical school applicants to the 2008 match tallied 2I34, of which $96 \%$ found positions. Of those, about $87 \%$ were accepted into I of their top- 3 choices of residency programs with respect to location and discipline. A total of 1299 internationally trained medical school graduates applied for residencies. Of those matched, about $23 \%$ were accepted into I of their top-3 program choices.

Of the I2I remaining residency positions, most are in family medicine, Banner said. "Forty percent of our positions were in family medicine, so, naturally, the bulk of our positions that went unfilled were in family medicine." — Roger Collier, CMAJ

DOI:Io.I503/cmaj.080639

\section{DISPATCH FROM THE MEDICAL FRONT}

\section{More casualties in Vietnam}

$\mathrm{F}$ orty-two years after United States marines first landed on its beaches, there are signs of increasing economic prosperity in $\mathrm{Da}$ Nang, Vietnam. Behind the rows of brightly coloured fishing boats stand advertisements for banks and electronics companies. Bamboo scaffolding surrounds the shells of new high-rise office towers on the banks of the Han River. Road traffic is increasingly motorized, with streams of motorcycles and their helmetless drivers weaving constantly on the streets.

Accompanying that road traffic, though, are an increasing number of deaths and injuries.

Among the physicians in Da Nang most acutely aware of the burdens associated with these injuries, including the social consequences and emotional impact on families, are neurosurgeons at the Da Nang Hospital, the city's 950bed tertiary-level public hospital.

After spending a month working as a resident on the neurosurgical service, the magnitude of the problem of road traffic-related neurotrauma became clear to me as well. The neurosurgical unit at the hospital has I02 beds but typically twice as many patients, most with brain injuries related to road traffic incidents.

The victims were of all ages: a 4-

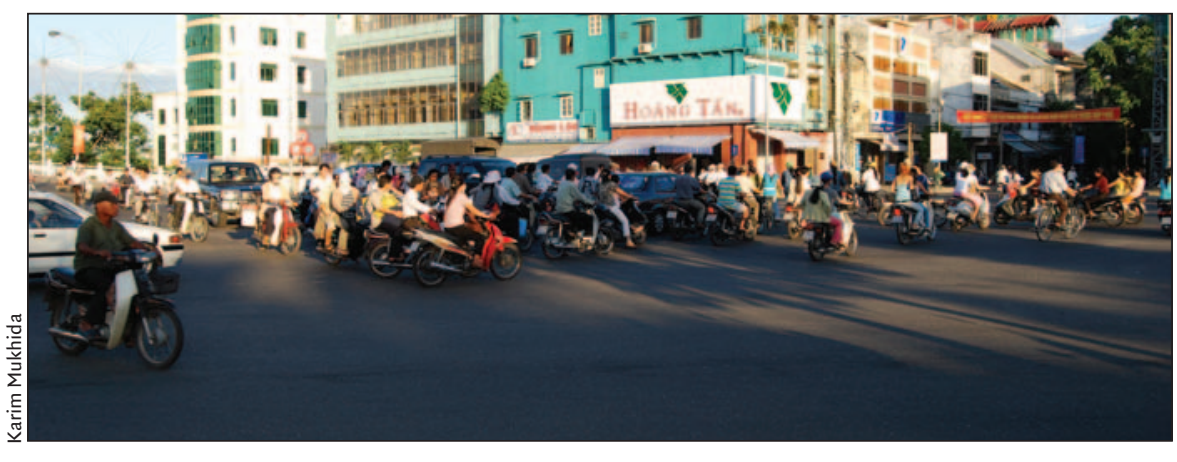

Major intersections in Da Nang, Vietnam, often resemble the start of motocross.

month-old girl who fell off her mother's lap and onto the road when the motorcycle on which they were traveling was clipped by a taxi; a 26year-old man who had consumed too much alcohol to celebrate a Vietnam victory in the Asian Cup and crashed his motorcycle while riding home; a 67-year-old man who was hit by a motorcycle as he was crossing the street.

It was common for 2 to 5 neurosurgical procedures to be performed daily for the evacuation of subdural or epidural hematomas, decompression of cerebral contusions or treatment of skull fractures related to road traffic incidents.

Space in the trauma operating rooms on the ground floor close to the emergency department was at a premium. I was actually surprised to hear a baby crying as we were evacuating an epidural hematoma and turned to see that another patient had been wheeled into the room on a stretcher to have a cesarean section performed.

It's projected that it will take 35 years before low-income countries like Vietnam see a decline in the incidence of road traffic fatalities to the level now seen in developed nations. That is too long to wait. - Karim Mukhida MD, Toronto, Ont.

DOI:I0.1503/cmaj.080600

CMAJ invites contributions to Dispatches from the medical front, in which physicians and other health care providers offer eyewitness glimpses of medical frontiers, whether defined by location or intervention. Submissions, which must run a maximum 400 words, should be forwarded to: wayne.kondro@cma.ca 